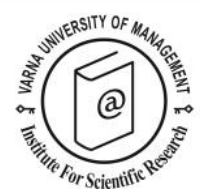

\title{
Communicating and promoting sustainability in tourism: An analysis of the official websites of the Italian regions
}

\author{
Riccardo Spinelli ${ }^{1 *}$
}

\author{
1 Department of Economics and Business Studies, University of Genoa (Italy). E-mail: \\ riccardo.spinelli@economia.unige.it \\ * Corresponding author
}

\begin{abstract}
This paper analyses the orientation towards sustainability in the online communication of the Italian regions, by evaluating - between December 2019 and January 2020 - the content of official tourism websites and assessing whether this orientation is associated with specific destination characteristics. Sustainability orientation is measured using the Green D-web, a checklist of 35 items of sustainability-oriented content. Destination profiling is assessed through the adoption of sustainable regulations and practices, the intensity of tourism development, and its size and maturity. Green D-web scores between 5 and 32 (out of a maximum of 35 ) are found with a median value of 19.5. Sustainability orientation is significantly and directly associated with both adoptions of sustainable regulations and practices and intensity of tourism development, while relationships with size and maturity are not significant.
\end{abstract}

Keywords: sustainable tourism, online communication, tourism websites, Italy, regions

Citation: Spinelli, R. (2021). Communicating and promoting sustainability in tourism: an analysis of the official websites of the Italian regions. European Journal of Tourism Research 29, 2916. 


\section{Introduction}

Sustainability is an essential perspective in the governance of tourism destinations (Borges et al., 2014; Del Chiappa et al., 2018; López-Sánchez and Pulido-Fernández, 2014), due to the economic, social and environmental impacts of such activities (UNEP and UNWTO, 2005; Lu and Nepal, 2009; Weaver, 2012) and growing awareness amongst tourists of the need to develop and protect local economies, environment and socio-cultural heritages (Budeanu, 2007; Del Chiappa et al., 2016). Tourists are becoming not just interested in "landscape, leisure \& learning" but also "limiting" the exploitation of local resources for tourism purposes (Franch et al., 2008). Other authors refer to "responsible tourism", as a "set of tourist practices that people embrace in order to discover the authenticity of the places they visit, preserving their scenic, natural, socio-cultural, economic, and environmental inheritance, becoming wealth promoters for the local hosting community and protesting against activities that blatantly disregard all these principles" (Del Chiappa et al., 2016, p. 193). Addressing the demands of such tourists represents a crucial driver of success for a destination, and an important marketing tool for destination management organizations (DMOs) (Ritchie and Crouch, 2005).

In this context, DMOs should be capable of measuring, reporting and disclosing their commitment towards sustainable tourism development (McLoughlin et al., 2018) to build a market position aligned with the evolving demand and competitive and socio-economic trends (UNWTO, 2010). DMOs' external communication activities are therefore crucial. Sustainability communication helps build an attractive image for the destination, reflecting the desirable values of transparency, solidarity, and equity (Ghanem and Elgammal, 2017).

Within the mix of communication tools, the official tourism website created by the DMO plays a primary role (Ali and Frew, 2013; Ip et al., 2011); official websites offer information on the local attractions and services, and often also have promotional and marketing functions as well (Luna-Nevarez and Hyman, 2012). DMOs should develop a website aligned with pursuing sustainability in terms of structure, content and services offered (Tölkes, 2018). Evaluation of this alignment is therefore a crucial issue, only partially explored in the literature. While many models have evaluated the quality of tourism websites (Law et al., 2010), much fewer studies have assessed the role and quality of destination websites for sustainability communication (D'Angella and De Carlo, 2016; Ettinger et al., 2018; Font et al., 2017; Garbelli et al., 2017; Ghanem and Elgammal, 2017). This study contributes to filling that gap by investigating the sustainability orientation of the official tourism websites for the Italian Regions and Autonomous Provinces (hereinafter, "Regions"). These are the public local authorities that are responsible for tourism policies and development in Italy.

\section{Methodology}

This research uses the methodology developed by D'Angella and De Carlo (2016) and applies it to exploring the websites of regional tourism destinations for their sustainability orientation. The analysis is divided into two steps. First, the sustainability-related content of the Italian regional tourism websites is evaluated. Second, the existence of a significant association between the intensity of the sustainability orientation and the destination profile is assessed.

The sustainability orientation of the websites is measured using the Green D-web, a website evaluation tool that D'Angella and De Carlo (2016) developed from Morrison et al. (1999). It is a checklist of 35 items (showed in Table 1), covering seven areas: general, infrastructures, transports, experience, food, shopping, and hospitality. The items are proxies for sustainability-oriented communication as they refer to forms of tourism, services, attractions, or accommodation facilities that are particularly concerned with economic, social and environmental impacts. 
The evaluator gives one point every time content related to an item is present in the website; the maximum score is therefore 35 .

Table 1. Green D-web items

\begin{tabular}{|c|c|}
\hline Area of analysis & Items \\
\hline General & $\begin{array}{l}\text { Information regarding green/sustainable/responsible travel [on the homepage] } \\
\text { Specific section regarding green/sustainable/responsible travel [inside the } \\
\text { website] } \\
\text { Green travel featured as a definite segment } \\
\text { Green travel tips } \\
\text { Green accreditation schemes } \\
\text { Climate change }\end{array}$ \\
\hline Infrastructures & $\begin{array}{l}\text { Carbon-offset options } \\
\text { Environmentally friendly attractions } \\
\text { Accessible areas or facilities }\end{array}$ \\
\hline Transports & $\begin{array}{l}\text { Green transport } \\
\text { Walking tours/holidays } \\
\text { Cycling or mountain bike tours/holidays } \\
\text { Tours using local transport } \\
\text { Low carbon travel }\end{array}$ \\
\hline Experience & $\begin{array}{l}\text { Green meetings/ events } \\
\text { Farming holidays } \\
\text { Volunteer travel } \\
\text { Information for backpackers } \\
\text { Wilderness tours/holidays } \\
\text { Birdwatching tours/holidays } \\
\text { Botany tours/holidays } \\
\text { Spa and wellbeing holidays } \\
\text { Photography tours/holidays }\end{array}$ \\
\hline Food & $\begin{array}{l}\text { Cooking activities/holidays } \\
\text { Food travel } \\
\text { Wine tasting tours/holidays } \\
\text { Vegetarian or vegan holidays }\end{array}$ \\
\hline Shopping & $\begin{array}{l}\text { Organic shopping tours } \\
\text { Ethical or eco-friendly shops }\end{array}$ \\
\hline Hospitality & $\begin{array}{l}\text { B\&B and guesthouses } \\
\text { Campsites and caravan parks } \\
\text { Eco-lodges hospitality } \\
\text { Farm stays accommodation } \\
\text { Accessible hotels } \\
\text { Lodgings with ecolabels or other certifications }\end{array}$ \\
\hline
\end{tabular}

Source: adapted from D’Angella and De Carlo (2016)

The destination profile is constructed from four variables, as described in Table 2: the level of adoption of sustainable regulations and practices, the rate of tourism development, the size, and the tourism maturity. The measurement of size and tourism maturity is the same as in D'Angella and De Carlo (2016), while original measures are proposed for the level of adoption of sustainable regulations and 
practices, and the tourism development. For the former, the “Eco city ranking index”, used in D'Angella and De Carlo (2016), is not available for Italian Regions and is replaced by the BES score; for the latter, the tourism pressure index is preferred to the ratio between international arrivals and the number of inhabitants, as it provides a better estimation of the proportion between tourist flows and locals.

Table 2. Profile variables

\begin{tabular}{lll}
\hline Variable & Measure & Source \\
\hline $\begin{array}{l}\text { Level of adoption of } \\
\text { sustainable regulations and } \\
\text { practices } \\
\text { Tourism development }\end{array}$ & $\begin{array}{l}\text { Score in the BES (Fair and Sustainable } \\
\text { Wellness) Report }{ }^{1}\end{array}$ & $\begin{array}{l}\text { Italian National Institute } \\
\text { of Statistics (2017) }\end{array}$ \\
Size & $\begin{array}{l}\text { Tourism pressure [100*total overnight } \\
\text { stays } /\left(365^{*} \text { permanent residents)] }\right. \\
\text { Permanent residents }\end{array}$ & $\begin{array}{l}\text { Italian National Institute } \\
\text { of Statistics (2018) } \\
\text { Tourism maturity } \\
\text { of Statistics (2018) }\end{array}$ \\
& $\begin{array}{l}\text { Variation in the total number of } \\
\text { overnight stays }(2014-2018)^{2}\end{array}$ & $\begin{array}{l}\text { Itan National Institute } \\
\text { of Statistics (2014, 2018) }\end{array}$ \\
\hline
\end{tabular}

Source: Author's assessment

As suggested by Weaver (2000), profile variables are transformed from continuous to discrete, discriminating with respect to the median value; the absolute values are therefore recoded as "high" or "low" depending on whether they were greater or less than the median value of their distribution. This transformation may oversimplify the data structure but minimizes the effect of any outliers. Verification of the existence of an association between the Green D-web score and the profile variables is then carried out by comparing the average Green D-web score between the two groups identified by "high" or "low" values of the profile variable.

\section{Findings and discussion}

Data collection took place between December 2019 and January 2020. The official tourism website of Calabria was offline during the entire period and so discarded. The final sample includes 20 websites, from the remaining 18 Regions and the two Autonomous Provinces of Bolzano and Trento (hereinafter, "Alto Adige" and "Trentino"). The list of websites is available on request.

Table 3 shows the variables values and the median of the distributions; the "Recoding" columns show the recoded discrete value corresponding to each continuous value.

The analysis returns Green D-web scores between 5 and 32, with a median value of 19.5. The websites richest in sustainability content belong to the northern and central Italian Regions, with Alto Adige and Trentino achieving the best results. Seven Regions - all in central-southern Italy, excepting Piemonte obtain less than 18/35 (the "pass" score), with the worst case of Molise scoring just 5.

The number of detected items varies a lot in the seven areas of the Green D-web tool. In the food area, 62 items were found out of a maximum of 80 (four attributes for 20 sites), with a $77.5 \%$ coverage: most websites host information on gastronomic and wine holidays, cooking activities, and vegan/vegetarian holidays. The other areas return good coverage, ranging between $54 \%$ and $67 \%$, with only the exception of the general area, whose coverage is less than $30 \%$. 
Table 3. Values of Green D-web score and profile variables

\begin{tabular}{|c|c|c|c|c|c|c|c|c|c|}
\hline \multirow[t]{2}{*}{ Region } & \multirow[t]{2}{*}{$\begin{array}{c}\text { Green } \\
\text { D-web } \\
\text { score } \\
{[0-35]}\end{array}$} & \multicolumn{2}{|c|}{$\begin{array}{c}\text { Adoption of } \\
\text { sustainable } \\
\text { regulations and } \\
\text { practices }\end{array}$} & \multicolumn{2}{|c|}{$\begin{array}{c}\text { Rate of } \\
\text { tourism } \\
\text { development }\end{array}$} & \multicolumn{2}{|c|}{ Size } & \multicolumn{2}{|c|}{$\begin{array}{l}\text { Tourism } \\
\text { maturity }\end{array}$} \\
\hline & & 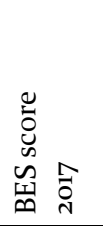 & 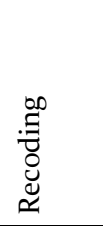 & 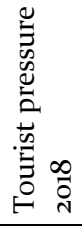 & 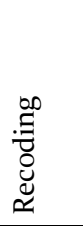 & 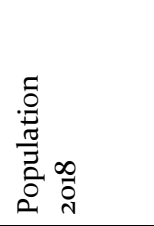 & 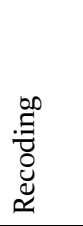 & 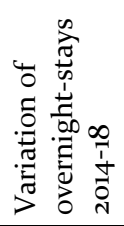 & 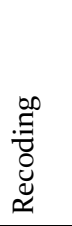 \\
\hline Abruzzo & 14 & 100.79 & Low & 1.32 & Low & $1,311,580$ & Low & $0.83 \%$ & High \\
\hline Alto Adige & 30 & 118.40 & High & 17.15 & High & 531,178 & Low & $16.99 \%$ & Low \\
\hline Basilicata & 19 & 95.81 & Low & 1.27 & Low & 562,869 & Low & $23.98 \%$ & Low \\
\hline Campania & 11 & 87.54 & Low & 1.02 & Low & $5,801,692$ & High & $20.10 \%$ & Low \\
\hline Emilia-Romagna & 23 & 111.37 & High & 2.50 & High & $4,459,477$ & High & $14.87 \%$ & Low \\
\hline $\begin{array}{l}\text { Friuli Venezia } \\
\text { Giulia }\end{array}$ & 23 & 110.34 & High & 2.03 & High & $1,215,220$ & Low & $18.61 \%$ & Low \\
\hline Lazio & 15 & 102.18 & Low & 1.71 & Low & $5,879,082$ & High & $19.07 \%$ & Low \\
\hline Liguria & 23 & 106.99 & Low & 2.68 & High & $1,550,640$ & Low & $12.68 \%$ & High \\
\hline Lombardia & 24 & 109.30 & High & 1.07 & Low & $10,060,574$ & High & $14.06 \%$ & High \\
\hline Marche & 18 & 107.26 & Low & 1.73 & Low & $1,525,271$ & Low & $-14.95 \%$ & High \\
\hline Molise & 5 & 99.42 & Low & 0.40 & Low & 305,617 & Low & $6.91 \%$ & High \\
\hline Piemonte & 16 & 107.62 & High & 0.95 & Low & $4,356,406$ & High & $15.61 \%$ & Low \\
\hline Puglia & 20 & 90.96 & Low & 1.03 & Low & $4,029,053$ & High & $14.49 \%$ & High \\
\hline Sardegna & 17 & 95.44 & Low & 2.50 & High & $1,639,591$ & High & $31.48 \%$ & Low \\
\hline Sicilia & 19 & 86.91 & Low & 0.83 & Low & $4,999,891$ & High & $1.80 \%$ & High \\
\hline Toscana & 24 & 109.10 & High & 3.50 & High & $3,729,641$ & High & $10.35 \%$ & High \\
\hline Trentino & 32 & 117.05 & High & 9.19 & High & 541,098 & Low & $18.13 \%$ & Low \\
\hline Umbria & 16 & 107.72 & High & 1.84 & High & 882,015 & Low & $1.34 \%$ & High \\
\hline Valle d'Aosta & 24 & 108.46 & High & 7.86 & High & 125,666 & Low & $20.76 \%$ & Low \\
\hline Veneto & 21 & 110.28 & High & 3.87 & High & $4,905,854$ & High & $11.91 \%$ & High \\
\hline Median & 19.5 & 107.44 & - & 1.79 & - & $1,595,116$ & - & $14,68 \%$ & - \\
\hline
\end{tabular}

No website explicitly mentions on its homepage green, sustainable or responsible travel and just five cases devote a specific section to these forms of tourism. Green travel is featured as a definite segment in three cases and only six websites provide advice and suggestions for sustainable travel. Climate change content is similarly limited, explored in just two websites with a focus on consequences for local mountains and glaciers. Green certifications and accreditation schemes are the only items that all websites (except Molise) show. However, most certifications are loosely related to sustainable tourism: protected origin designation for food and wine, blue flags (for the quality of beaches), orange flags (given to the most beautiful Italian villages) and green flags (for "child-friendly" destinations). Only in Alto Adige, Piemonte and Trentino are certifications strictly linked to sustainability issues, such as the presence of "100\% renewable" municipalities in Alto Adige, the recognition of "Biosphere Reserve" for some parks in Piemonte, quality brands such as "Trentino Quality Mark" and "Ecoristorazione Trentino" or certifications such as "Green Way Primiero" (circular economy), "PEFC - Programme for the Endorsement of Forest Certification schemes" (sustainable management of forest resources) and "EMAS - Eco-Management and Audit Scheme" (environmental performance).

The association between the sustainability orientation of communication and the destination profile was verified by comparing the average Green D-web score of the two subgroups of destinations, identified by a "high" or "low" value of the profile variables. First, the normality of the distribution of 
Green D-web scores was assessed for all sub-distributions built with profiling variables as grouping factors (i.e. Green D-web scores with high \& low BES score, with high \& low tourist pressure etc.). Shapiro-Wilk's test was used, as it was developed specifically to test whether a distribution is normal and is considered particularly sensitive to a wide range of non-normality (from asymmetry to long- and short-tailedness), even with samples as small as $n=20$ (Shapiro and Wilk 1965). All the eight tests on Green D-web scores sub-distributions (high \& low subgroups for the four profiling variables) were nonsignificant, with the test p-values ranging from .096 to .866. In the light of these outcomes, normality distribution of data was assumed. As data was measured with scale (ranging from o to 35) and intrinsically independent, it was appropriate to compare average scores with a parametric test (the independent sample T-test), after a preliminary Levene's test for the equality of variances. The results are shown in Table 4 .

Table 4. Levene's and T-test results

\begin{tabular}{|c|c|c|c|c|c|c|}
\hline \multirow[t]{2}{*}{ Variable } & \multicolumn{2}{|c|}{$\begin{array}{l}\text { Average sub-group } \\
\text { Green D-web score }\end{array}$} & \multicolumn{2}{|c|}{ Levene's test } & \multicolumn{2}{|c|}{$\begin{array}{l}\text { T-test } \\
t(18)\end{array}$} \\
\hline & Low & High & $\mathrm{F}$ & $\mathrm{p}$ value & $\begin{array}{l}\text { Test } \\
\text { value }\end{array}$ & $\mathrm{p}$ value \\
\hline $\begin{array}{l}\text { Level of adoption of } \\
\text { sustainable regulations and } \\
\text { practices }\end{array}$ & 16.10 & $23 \cdot 30$ & .065 & .802 & -3.141 & $.006^{*}$ \\
\hline Tourism development & 16.10 & 23.30 & .126 & .727 & -3.141 & $.006^{*}$ \\
\hline Size & 19.0 & 20.4 & 2.465 & .134 & .494 & .627 \\
\hline Tourism maturity & 18.4 & 21.0 & .622 & .441 & .933 & .363 \\
\hline
\end{tabular}

A significant association exists between the sustainability orientation of online communication and the adoption of sustainable regulations and practices. Destinations more sensitive to sustainability issues express this orientation in their tourism communication. This is reflected in their websites through content that recalls and suggests environmentally and socially respectful tourism activities.

Similarly, sustainability orientation and tourism development are significantly associated. Destinations most markedly affected by incoming tourist flows share the same approach. This is for two reasons: on the one hand, strong pressure may encourage local decision-makers to focus on more sustainable forms of tourism; on the other hand, attention to sustainability may have made these destinations more attractive for tourists whose decisions are increasingly influenced by sustainability issues.

There is no significant difference in the sustainability orientation of destinations with high and low size; the implementation of sustainability communication policies is therefore a marketing tool available to all destinations. Finally, the orientation towards sustainability is not associated with the tourism maturity of the destination; efforts in this direction can consequently help stimulate destination development, consolidate its results or even trigger a relaunch.

\section{Conclusions}

This paper investigates the orientation towards sustainability in online tourism communication by Italian Regions and its association with structural features of the destinations. Previous studies (Baggio et al., 2011; Pencarelli et al., 2011; De Carlo, 2013) have analysed the quality of the official tourism websites of Italian Regions but this work is the first to assess their orientation towards sustainability. 
The analysis returns a picture of variable performances. These results confirm Ghanem and Elgammal (2017)'s outcomes, as the majority of the national tourism websites in their sample also lacked an appropriate and complete approach to sustainability communication. Interestingly, the association between the sustainability orientation of online communication and the profile variables fully reflects the outcomes of D'Angella and De Carlo (2016). Both in their study on city websites and in ours, the adoption of sustainable regulations and practices and the degree of tourism development of the destinations are significantly and positively associated with the sustainability orientation of web communication, while size and maturity do not play any role.

The study has implications for scholars and practitioners. Scholars may be interested in the variable coverage of the seven areas explored by the Green D-web tool; future research may assess whether the websites of other destinations share a similar profile and investigate the reasons underlying the uneven communication of different facets of sustainability. The outcomes confirm the robust association between sustainability communication, adoption of sustainable regulations and practices, and tourism development, thus contributing to the debate on the determinants of sustainability communication by tourism destinations. Practitioners are provided with a tool to assess the sustainability orientation of destination websites, together with a comprehensive picture of the performances of regional tourism websites in Italy, one of the most important destinations worldwide. Destination managers may use the approach to benchmark their websites and improve their sustainability orientation.

The study also has some limitations. Focusing on just the websites, it ignores other ways of online communication; specific attention should be paid, in particular, to social media, whose role in the communication of destinations is increasingly important (Leung et al., 2013). Another relevant issue is the use of a counting tool such as the Green D-Web: the need to provide binary evaluations (presence or absence of an item), while potentially reducing the subjectivity of the analysis, also deprives researchers of a finer evaluation grid. Finally, the list of items may be integrated to assess missing aspects such as the reference to the Sustainable Development Goals and the contribution of local tourism activities to their achievement (UNWTO \& UNDP, 2017).

The analysis was performed before the Covid-19 pandemic, which deeply affected the tourism market and especially stimulated a greater concern by tourists for greener, more authentic, and off-the-beatentrack experiences (Benjamin et al., 2020; Gössling et al., 2021; Romagosa, 2020). Future research may replicate the study in an "ongoing" or "post-pandemic" setting, to assess whether the Italian Regions increased the sustainability orientation of their tourism websites in response to this trend.

\section{Endnotes}

${ }^{1}$ The BES Report, edited by the Italian National Institute of Statistics - Istat, evaluates the progress of society from economic, social and environmental points of view. It includes a large set of indicators divided into 12 domains: health; education and training; work and life balance; economic well-being: social relationships; politics and institutions; security; subjective well-being; landscape and cultural heritage; environment; innovation, research and creativity; and quality of services. As the BES report only includes the score for each domain, the average of the 12 scores was used as an overall BES score for each Region.

${ }^{2}$ A low or negative variation signals high maturity or decline, while a high value suggests low maturity, as the destination is still experiencing growth in visits 


\section{References}

Ali, A., Frew, A.J. (2013), Information and communication technologies for sustainable tourism. New York: Routledge.

Baggio, R., Mottironi, C., Antonioli Corigliano, M. (2011). Technological aspects of public tourism communication in Italy. Journal of Hospitality and Tourism Technology, 2(2), 105-119. https://doi.org/10.1108/17579881111154227

Benjamin, S., Dillette, A., Alderman, D.H. (2020). "We can't return to normal”: Committing to tourism equity in the post-pandemic age. Tourism Geographies, 1-8.

https://doi.org/10.108o/14616688.2020.1759130

Borges, M., Eusébio, C., Carvalho, N. (2014). Governance for sustainable tourism: A review and directions for future research. European Journal of Tourism Research, 7(1), 45-56. https://ejtr.vumk.eu/index.php/about/article/view/139/138

Budeanu, A. (2007). Sustainable tourist behaviour-a discussion of opportunities for change. International Journal of Consumer Studies, 31(5), 499-508. https://doi.org/10.1111/j.14706431.2007.00606.x

D'Angella, F., De Carlo, M. (2016). Orientation to sustainability and strategic positioning of destinations: an analysis of international tourism websites. Current Issues in Tourism, 19(7), 624633. http://dx.doi.org/10.108o/13683500.2014.965133

De Carlo, M. (2013). La valutazione della strategia di destinazione. Uno studio sui portali turistici nazionali e internazionali, Milano: Franco Angeli.

Del Chiappa, G., Grappi, S., Romani, S. (2016). Attitudes toward responsible tourism and behavioral change to practice it: A demand-side perspective in the context of Italy. Journal of Quality Assurance in Hospitality \& Tourism, 17(2), 191-208. http://dx.doi.org/10.1080/15280o8X.2015.1115254

Ettinger, A., Grabner-Kräuter, S., Terlutter, R. (2018). Online CSR communication in the hotel industry: Evidence from small hotels. International Journal of Hospitality Management, 68, 94-104. http://dx.doi.org/10.1016/j.ijhm.2017.09.002

Font, X., Elgammal, I., Lamond, I. (2017). Greenhushing: The deliberate under communicating of sustainability practices by tourism businesses. Journal of Sustainable Tourism, 25(7), 1007-1023. https://doi.org/10.108o/o9669582.2016.1158829

Franch, M., Martini, U., Buffa, F., Parisi, G. (2008). 4L Tourism (landscape, leisure, learning and limit): Responding to new motivations and expectations of tourists to improve the competitiveness of Alpine destinations in a sustainable way. Tourism Review, 63(1), 4-14. https://doi.org/10.1108/16605370810861008

Garbelli, M., Adukaite, A., Cantoni, L. (2017). Value perception of world heritage sites and tourism sustainability matters through content analysis of online communications. Journal of Hospitality and Tourism Technology, 8(3), 417-431. https://doi.org/10.1108/JHTT-09-2016-0046

Ghanem, M., Elgammal, I. (2017). Communicating sustainability through a destination's website: A checklist to inform, motivate, and engage stakeholders, Journal of Travel E Tourism Marketing, 34(6), 793-805. https://doi.org/10.1080/10548408.2016.1233928

Gössling, S, Scott, D., Hall, C.M. (2021) Pandemics, tourism and global change: a rapid assessment of COVID-19, Journal of Sustainable Tourism, 29(1), 1-20. https://doi.org/10.108o/o9669582.2020.1758708

Ip, C., Law, R., Lee, H.A. (2011). A review of website evaluation studies in the tourism and hospitality fields from 1996 to 2009. International Journal of Tourism Research, 13(3), 234-265. https://doi.org/10.1002/jtr.815

Law, R., Qi, S., Buhalis, D. (2010). Progress in tourism management: A review of website evaluation in tourism research. Tourism Management, 31, 297-313. https://doi.org/10.1016/j.tourman.2009.11.007 
Leung, D., Law, R., Van Hoof, H., Buhalis, D. (2013). Social media in tourism and hospitality: A literature review. Journal of Travel E Tourism Marketing, 30(1-2), 3-22. https://doi.org/10.108o/10548408.2013.750919

López-Sánchez, Y., Pulido-Fernández, J.I. (2014). Incorporating sustainability into tourism policy: A strategic agenda for Spain. European Journal of Tourism Research, 7(1), 57-78. https://ejtr.vumk.eu/index.php/about/article/view/140/139

Lu, J., Nepal, S.K. (2009). Sustainable tourism research: An analysis of papers published in the Journal of Sustainable Tourism. Journal of Sustainable Tourism, 17(1), 5-16. https://doi.org/10.108o/o9669580802582480

Luna-Nevarez, C., Hyman, M. R. (2012). Common practices in destination website design. Journal of Destination Marketing \& Management, 1(1-2), 94-106. https://doi.org/10.1016/j.jdmm.2012.08.002

McLoughlin, E., Hanrahan, J., Duddy, A.M., Duffy, S. (2018). European tourism indicator system for sustainable destination management in county Donegal, Ireland. European Journal of Tourism Research, 20, 78-91. https://ejtr.vumk.eu/index.php/about/article/view/341/345

Morrison, A.M., Taylor, J.S., Morrison, A.J., Morrison, A.D. (1999). Marketing small hotels on the World Wide Web, Information Technology E Tourism, 2(2), 97-113. https://www.ingentaconnect.com/contentone/cog/itt/1999/ooooooo2/ooooooo2/artoooo3

Pencarelli, T., Cioppi, M., Splendiani, S. (2011). Web communication nel turismo. Analisi dei portali turistici delle regioni italiane. Paper presented at XXIII Sinergie Conference, 1oth-11th November 2011, Milano (Italy).

Ritchie, J.R.B., Crouch, G.I. (2005). The competitive destination: A sustainable tourism perspective. Oxon: CABI Publishing.

Romagosa, F. (2020). The COVID-19 crisis: Opportunities for sustainable and proximity tourism. Tourism Geographies, 1-5. https://doi.org/10.1080/14616688.2020.1763447

Shapiro, S.S., Wilk, M.B. (1965). An analysis of variance test for normality (complete samples). Biometrika 52, 591-611. https://www.jstor.org/stable/2333709

Tölkes, C. (2018). Sustainability communication in tourism - A literature review. Tourism Management Perspectives, 27, 10-21. https://doi.org/10.1016/j.tmp.2018.04.002

UNEP \& UNWTO (2005), Making tourism more sustainable: A guide for policy makers. Paris - Madrid: UNWTO. https://wedocs.unep.org/handle/20.500.11822/8741

UNWTO (2010), Survey on destination governance. Evaluation report, Madrid: UNWTO.

UNWTO \& UNDP (2017). Tourism and the sustainable development goals - Journey to 2030. UNWTO, UNDP, and PWC, Madrid. https://www.e-unwto.org/doi/book/10.18111/9789284419401

Weaver, D.B. (2000). A broad context model of destination development scenarios. Tourism Management, 21(3), 217-224. https://doi.org/10.1016/So261-5177(99)00054-o

Weaver, D.B. (2012). Organic, incremental and induced paths to sustainable mass tourism convergence. Tourism Management, 33(5), 1030-1037. https://doi.org/10.1016/j.tourman.2011.08.011

Received: 11/01/2021

Accepted: 02/02/2021

Coordinating editor: Giacomo Del Chiappa 